\title{
The Effect of Process Approach on Students' Writing Competency at SMK Negeri 1 Kubutambahan Bali
}

\section{Gede Sukanaya*}

Universitas Pendidikan Ganesha

\section{A R T I C L E I N F O \\ Article history: \\ Received February \\ 2020 \\ Received in revised \\ Form 01 March 2020 \\ Accepted 18 April 2020 \\ Available online 30 May \\ 2020}

Keywords:

Process Approach, Writing, EFL

\begin{abstract}
A B S T R A C T
This study is intended to explore the effect of process approach on students' writing competency at SMK Negeri 1 Kubutambahan Bali. This study was experiment with pretest-posttest design. This study involved 33 students and the experiment was conducted three months. The data were collected through writing test. The data were analyzed using descriptive and inferential analysis.. The result shows that the students' mean score in pretest was 6.3 and the students' mean score in posttest was 7.7. The result of t test shows a significant difference between pretest and posttest with Sig. (2-tailed) $=0.000$. It is suggested that English teacher should be focusing on the process of writing instead of product especially for English students who are still having low language proficiency. The result of the study implies that writing is a process. Writing is a process. In the process, the role of revision, which includes comments and suggestions are very helpful for students in improving their writing.
\end{abstract}

\section{Introduction}

Currently, education in Indonesia is being confronted with the fact of the low level of student literacy. This can be seen from the results of the PISA (Program for International Student Assessment) published in 2019. PISA is a test initiated by the Organization for Economic Cooperation and Development (OECD) to evaluate the education system in 72 countries surveyed (Kusnandar, 2019). In this survey, students aged 15 years were randomly selected to take the basic competency test in reading, mathematics, and science. This survey is to measure what students can apply from the knowledge they have acquired. Results (PISA) Indonesia stated that the Reading Performance score or reading ability / interest of Indonesian students was valued at 409 in 2015 and in 2019 decreased to 380. This placed Indonesia at the bottom while the highest ranking was achieved by Singapore with a score of 525. The level of studentliteracy students in Indonesia are still low compared to students from other countries.

In addition to the PISA results, from the preliminary analysis of the results of the National Examination for English subjects as parameters of the success of English education and teaching, showing unsatisfactory results, especially in Bali. For three years $(2017,2018,2019)$ it turns out that there are still many students in the category of adequate mastery (range of scores from 4.50 to 5.49) and less (range of scores from 4.50 to 5.49). This indicates that there needs to be an increase in the English learning and teaching sector in order to produce human resources with better English skills.

English mastery becomes a compulsory competence in the current era of globalization. However, English Proficiency in Indonesia is not quite satisfying. Valentina (2016) reported that Indonesia is ranked 32nd out of 72 countries in the 2016 English First English Proficiency Index (EF EPI) based on research conducted by the international education company English First (EF).With a score of 52.91, the study put Indonesia below Vietnam, which ranked 31st and fell under the Moderate Proficiency Band category. 
Surprisingly, Indonesia fell seven spots from the previous year, Indonesia has been ranked 39th out of 80 countries in 2017. The average score in Asian countries is 53.60, according to the report. With a score of 52.15, Indonesia is below the regional average and part of the Low Proficiency Band category.

It is widely accepted that mastering a foreign language is a difficult task. Indonesian students do not use English as their daily communication so they have limited time to practice English (Mayristanti, 2016). Besides that, there are four skills should be mastered namely speaking, writing, reading and listening. Among the four skills, writing requires a special intention since it is a productive skill (Kestha \& Harb, 2013). Marhaeni (2014) supports that writing ability is one of the most complex language skills because it involves a variety of cognitive and linguistic abilities. Because it is the most complex, learning to write is considered the most difficult. This difficulty is not only based on cognitive and linguistic problems, but also on psychological problems (Rahmatunisa, 2014). In addition to complexity, writing is a very active process that allows writers to write based on words and ideas in making meaning over ideas and topics developed (Anwar \& Ahmed, 2016).

Expressing feelings and ideas can be done in written form. Writing presents the sounds of language through visual symbols (Patel \& Jain, 2008). Writing is a skill that must be taught and practiced. Writing is an important feature in learning languages because it provides an excellent tool for learning vocabulary, spelling, and sentence patterns. However, many studies have found that the development of students' writing skills is hampered by the limitations of ideas and most often expressed is the problem of language components. In addition, strategies in teaching writing that focus on product quantity become an obstacle in the learning process of writing primarily for students who are new to learning English. Therefore, it is necessary to have a more effective approach in teaching writing skills.

The process approach is widely offered and recommended in teaching writing skills. The process approach is based on constructivism theory. In here, the students construct their understanding toward particular thing (Aric \& Kaldirim, 2015; Ghufron, 2016). In process writing, there are several writing stages. Commonly those stages are prewriting, drafting, editing, revising, and publishing (Bayat, 2014). Furthermore, Marhaeni (2014) states that to maximize student writing, teachers need to see that writing is a systematic and gradual process.

The results of previous studies show positive results on the implementation of the process approach to students' writing skills. Bayat (2014) examined the effects of the process writing approach on student success and writing anxiety. The results found that the writing process approach has a significant effect on the success and anxiety of writing. He process writing approach is especially effective in alleviating the dimension of writing anxiety associated with language skill. Samsudin (2015) compared the process approach with the product approach in teaching academic writing. The participants of process approach show better improvement than those of product approach in terms of content, organization, mechanics and overall results. Students become more confident in the process of learning to write because of the teacher's assistance and the absence of pressure to finish writing with a time limit. Alabere and Shapii (2019) also identified that students' academic writing was improved after process approach is conducted.

The process approach can have a positive impact on students' motivation in learning English and developing their writing skills (Miftah, 2015, Mehr, 2017). This means that the assessment process can encourage students to write even in cases where they were initially afraid to do so, for example, afraid of making mistakes. In addition, it can also regulate and enhance students' self-esteem, interests and selfesteem because they can go through non-rigid process stages (Hidayati, 2018). Shaarawy (2014) adds that writing using a process approach will help students develop critical thinking skills. So it can be said that the process approach helps students to learn actively and motivates them to improve their writing skills in English.

The reason of emphasizing the use of process approach is because of students' low writing achievement is due to lack of process. Eliwarti and Maarof (2014) state that the use of product approach gives little role in process of producing writing such as planning, drafting, revising, etc. Besides that, the product approach is criticized because it is no longer suitable with the current learning situation that is focusing on individual learning and processes of the mind rather than product (Palpanadan, Salam, \& Ismail, 2014, Khanjani, Vahdany, Jafarigohar, 2018). Seeing the benefits of applying the process approach, this research investigates the effect of the process approach on student writing skills at SMK Negeri 1 Kubutambahan Bali. 


\section{Methods}

This research is an experimental research design with pretest-posttest design. This research involved 33 students. The students firstly asked to write a narrative text as the pretest of the study. After conducting pretest, the process approach is implemented. After several implementation of process approach, the students are asked to write a narrative text as the posttest of the study. The students' writing were analyzed based on five components, namely content, organization, grammar, vocabulary and mechanics. Data analysis involved descriptive and inferential statistics.

\section{Result And Discussion}

The first analysis carried out was descriptive analysis. The results can be seen in Table 1 .

Table 1. Descriptive Analysis

\begin{tabular}{lcccccc}
\hline & \multicolumn{5}{c}{ Component } & \multirow{2}{*}{ Mean } \\
\cline { 2 - 6 } & Content & Organization & Grammar & Vocabulary & Mechanics & \\
\hline Pretest & 2.57 & 2.67 & 2.70 & 2.23 & 2.43 & 6.36 \\
Posttest & 3.20 & 3.20 & 3.03 & 2.87 & 3.07 & 7.76 \\
\hline
\end{tabular}

From the results of descriptive analysis, it can be seen that the posttest score is higher than the pretest from all components of writing skills assessment. From the mean score, it can also be seen that the posttest score (7.76) is higher than the pretest (6.36). Next, an inferential test is performed to find out whether there is a significant difference between pretest and posttest. The inferential test results can be seen in Table 2.

Table 2. Inferential Statistics

\begin{tabular}{cc}
\hline & Posttest - Pretest \\
\hline $\mathrm{Z}$ & $-4.755^{\mathrm{b}}$ \\
Asymp. Sig. (2-tailed) & .000 \\
\hline
\end{tabular}

a. Wilcoxon Signed Ranks Test

b. Based on negative ranks.

From the results of the non-parametric test, it was found that the Asymp value. Sig. (2-tailed) is .000 . This characterizes that there is a significant difference between pretest and posttest. It can be said that students' writing grades get better after the process approach is used as a teaching strategy.

The results in this study are in line with several previous studies that have been conducted. They found that the process approach had a positive impact on students' writing skills (Dilidüzgün, 2013; Dayat, 2014; Alodwan \& Ibnian, 2014; Arici \& Kaldirim, 2015, Li, Chu, Ki, 2016; Adula, 2018). In the approach process, students' writing gets positive feedback so they know the mistakes and are motivated to correct them (Downs, 2015; Pacello, 2019). The students are engaged during the process approach and they able to develop their creativity in constructing words, sentences and meaningful paragraph (Faraj, 2015; Papilaya, 2018; Imelda, Cahyono, Astuti, 2019).

However, the obstacle in the process approach is a long time in the process of making the writing. Although there was a lot of input and discussion between teachers and students, students had not been able to finish writing in a short time. In this study, a writing can be completed by students within 3-4 weeks. Other research also states that the use of the process approach is very time consuming (Palpanadan, Salam \& Ismail, 2014; Eliwarti \& Maarof, 2017). Besides that, time factor becomes an obstacle in the process approach when teaching in large classes (Dokchandra, 2018). Therefore, teachers need to pay attention to aspects of time in the implementation of the process approach.

The results of the study prove that the process approach has a positive impact on students' writing skills at SMK N 1 Kubutambahan. This can be seen from the results of writing skills assessed from five components before the process approach is treated. Descriptive and inferential analysis results also prove that there is a significant difference before and after the process approach is implemented. 


\section{Conclussion}

The study concludes that process approach significantly affect students' writing. After process approach was implemented, the students' posttest score was higher than pretest score. Further study is recommended to conduct another influencing factor in determining the success of writing such as anxiety and motivation and see how those factor influence students' writing.

\section{Reference}

Adula H. (2018). The Practice of Process Approach in Writing Classes: Grade Eleven Learners of Jimma Preparatory and Jimma University Community Preparatory School in Focus. International Journal of English and Literature, 9(5), 39-49.

Alabere, R., and Shapii, A. (2019). The Effects of Process-Genre Approach on Academic Writing. J. Eng. Educ. Society. 4(2), 89-98.

Khanjani, A., Vahdany,F., Jafarigohar, M. (2018). Effects of Journal Writing on EFL Teacher Trainees' Reflective Practice. Research in English Language Pedagogy, 6(1),56-77.

Alodwan, T. and Ibnian, S. (2014). The Effect of Using the Process Approach to Writing on Developing University Students' Essay Writing Skills in EFL. Review of Arts and Humanities, Vol. 3, No. 2, pp. 139-155.

Anwar, M., \& Ahmed, N. (2016). Students' Difficulties in Learning Writing Skills in Second Language. Lahore, 2(4), 727-735.

Arici, A. and Kaldirim, B. (2015). The Effect of the Process-based Writing Approach on Writing Success and Anxiety of Pre-service Teachers. Anthropologist, 22(2): 318-327

Bayat, N. (2014). The Effect of the Process Writing Approach on Writing Success and Anxiety. Educational Sciences: Theory \& Practice, 14(3), 1133-1141.

Dokchandra, D. (2018). The Effects of Process Writing Approach on Performance of an Overcrowded EFL Writing Class at a University in Thailand. The 1st Annual International Conference on Language and Literature (AICLL), 191-206. DOI 10.18502/kss.v3i4.1931

Downs, D. (2015). Revision is central to developing writing. In L.A. Kassner \& E. Wardle (Eds.) Naming what we know: Threshold concepts of writing studies. Boulder, CO: University Press of Colorado.

Eliwarti and Maarof, D. (2014). The Effects of Types of Writing Approaches on Efl Students'Writing Performance. SELT 2014, Padang, June 11-12, pp.112-119.

Eliwarti and Maarof, D. (2017). The Students' Perceptions of the Strategies in the Process Approach. International Journal of Educational Best Practices, 1(1), 73-91.

Faraj, A. (2015). Scaffolding EFL students' writing through the writing process approach. Journal of Education and Practice, 6, 131-141.

Ghufron, M. (2016). Process-Genre Approach, Product Approach, and Students' Self-Esteem in Teaching Writing. Indonesian EFL Journal: Journal of ELT, Linguistics, and Literature, 2(1), 37-54.

Hidayati, H. (2018). Teaching Writing to EFL Learners : An Investigation of Challenges Confronted by Indonesian Teachers. LANGKAWI Journal, 4(1), 21-31. 
Imelda, Cahyono, B. Astuti, U. (2019). Effect of Process Writing Approach Combined with Video-Based Mobile Learning on Indonesian EFL Learners' Writing Skill across Creativity Levels. International Journal of Instruction, 12(3), 325-340.

Kestha. S. \& Harb., I. (2013). The Effectiveness of Blended Learning Program on Developing Palestinian Tenth Graders' English Writing Skills. Educational Journal. Vol 2, No. 6,, 208-221.

Kusnandar, V. (2019). Tingkat Literasi Pelajar Indonesia Masih Rendah", diunduh dari https://databoks.katadata.co.id/datapublish/2019/09/30/tingkat-literasi-indonesia-masihrendah. Accessed November 2019

Li, X., Chu, W., \& Ki, W. (2014). The effects of a wiki-based collaborative process writing pedagogy on writing ability and attitudes among upper primary school students in Mainland China. Computers \& Education, 77, 151-169.

Marhaeni, A.A.I.N. (2014). Toward Authentic Language Assessment: A Case in Indonesian EFL Classrooms.The European Conference on Language Learning (pp. 1-15)

Mayristanti, (2016). The Effect of Using Flashcards on Students'Vocabulary Achievement (Thesis). SyarifHidayatullah State Islamic University.

Mehr, H. (2017). The Impact of Product and Process Approach on Iranian EFL Learners' Writing Ability and Their Attitudes toward Writing Skill. International Journal of English Linguistics, 7(2), 158166.

Miftah, Z. (2015). Enhancing Writing Skill Through Writing Process Approach. Journal on English as Foreign Language, 5(1), 9-24.

Pacello, J. (2019). Cultivating a Process Approach to Writing: Student Experiences in a Developmental Course. Journal of the Scholarship of Teaching and Learning, 19(2),187-197.

Palpanadan, S. Salam, A. \& Ismail, F. (2014). Comparative Analysis of Process Versus Product Approach of Teaching Writing in Malaysian Schools: Review of Literature. Middle-East Journal of Scientific Research 22 (6): 789-795

Papilaya, R. (2018). Effect of process approach combined with internet resources through mobile phone on EFL students' ability in writing. (Unpublished master's thesis). Universitas Negeri Malang, Malang.

Patel, F., and Jain, P. (2008) English Language Teaching (Methods, Tools \& Techniques). Sunrise: UK.

Rahmatunisa, W.(2014). Problems Faced by Indonesian EFL Learners in Writing Argumentative Essay." Journal of English Education, 3(1), 1-9.

Samsudin, Z. (2015). Comparing the Process Approach with the Product Approach in Teaching Academic Writing to First-year Undergraduates. Proceedings of the International Seminar on Language Teaching ISeLT, pp. 1-22.

Shaarawy. H. (2014). The Effect of Journal Writing on Students' Cognitive Critical Thinking Skills. International Journal of Higher Education, 3(4), 120-128.

Valentina, J. (2017).Indonesia falls in 2017 English proficiency index. The Jakarta Post. [online] Available at:https://www.thejakartapost.com/life/2017/12/13/indonesia-falls-in-2017-englishproficiency-index.html [Accessed January 25th. 2020]. 